\title{
PENGARUH FASILITAS BELAJAR DAN MOTIVASI BELAJAR TERHADAP HASIL BELAJAR SISWA PADA MATA PELAJARAN EKONOMI
}

\author{
Irfan Hendra Anggryawan \\ Pendidikan Ekonomi, Jurusan Pendidikan Ekonomi, Fakultas Ekonomi, Universitas Negeri Surabaya, e-mail: \\ irfananggryawan@mhs.unesa.ac.id
}

\begin{abstract}
Abstrak
Pendidikan di Indonesia sangat diperhatikan perkembangannya. Hasil belajar seseorang bisa dipengaruhi oleh motivasinya dalam belajar serta fasilitas yang menunjang. Penelitian ini bertujuan untuk mengetahui pengaruh motivasi belajar serta fasilitas saat belajar terhadap hasil belajar peserta didik pada mata pelajaran ekonomi. Metode penelitian yang digunakan yaitu analisis regresi linier berganda. Sebanyak 79 orang siswa dijadikan sampel dalam penelitian ini. Hasil penelitian menunjukkan bahwa (1) hasil belajar dipengaruhi secara signifikan dan positif oleh motivasi belajar. (2) hasil belajar dipengaruhi secara signifikan dan positif oleh motivasi belajar. (3) fasilitas belajar dan motivasi belajar berpengaruh signitifikan dan positif pada hasil belajar.

Kata Kunci : Hasil belajar, Fasilitas belajar, motivasi belajar
\end{abstract}

\section{Abstract}

In Indonesia education is one of the factors that has been considered in its development. There are several factors that affect learning outcomes, namely learning facilities and learning motivation. This study aims to determine the effect of learning facilities and learning motivation on student learning outcomes in economic subjects. The method in this research is multiple linear regression analysis. The sample used in this study were 79 students. The results showed that (1) learning facilities has a positive and significant effect on learning outcomes. (2) learning motivation has a positive and significant effect on learning outcomes. (3) learning facilities and learning motivation have a positive and signitificant effect on learning outcomes.

Keywoard : Learning facilities, learning motivation, learning outcomes

\section{PENDAHULUAN}

Di Indonesia pendidikan ialah salah satu faktor yang telah diperhatikan dalam perkembangannya. Menurut Sardiman (2011) Pendidikan merupakan usaha sadar untuk perubahan tingkah laku menuju suatu kedewasaan. Pendidikan selalu dikaitkan dengan kegiatan pembelajaran. Belajar mengajar merupakan kegiatan fundamental, artinya cara proses belajar menentukan berhasil tidaknya dalam mencapai tujuan pendidikan. Tolok ukur terjadinya suatu proses keberhasilan dalam pembelajaran yang dilakukan sebelumnya dapat diukur melalui nilai. Keberhasilan siswa dalam proses pembelajaran berarti siswa tersebut berhasil dalam penguasaan materi atau konsep sehingga mendapatkan hasil belajar yang optimal (Astuti dan Sukardi, 2012).

Menurut hasil pra penelitian awal yang telah dilakukan di SMA Muhammadiyah 4 Surabaya yang terletak di jalan Kemlaten Baru 43, Surabaya diperoleh informasi bahwa nilai KKM pada mata pelajaran Ekonomi sebesar 80, sedangkan nilai rata-rata siswa diketahui masih banyak yang memperoleh nilai dibawah 80. Hal tersebut tidak sesuai dengan teori (Slameto, 2010) yaitu keberhasilan pendidikan diketahui dari perolehan hasil belajar yang optimal sesuai dengan tolok ukur nilai yang ada di sekolah. Fasilitas belajar yang lengkap merupakan salah satu faktor peserta didik endapatkan hasil belajar yang baik. Fasilitas belajar adalah komponen yang bersumber pada alat pembelajaran seperti sarana- prasarana dan gedung sebagai tempat berlangsungnya kegiatan belajar mengajar. Hasil belajar peserta didik dipengaruhi oleh fasilitas belajarnya (Aunurrahman, 2014). Hasil belajar peserta didik selain dipengaruhi oleh fasilitas belajar juga dipengaruhi oleh motivasi belajarnya. Motivasi bisa menggerakkan sesorang untuk bertingkah laku guna mencapai tujuan yang diinginkan (Listyanto, 2013).

Motivasi belajar setiap siswa berbeda-beda, begitu pula dengan kondisi siswa di SMA Muhammdiyah 4 Surabaya yang memiliki perbedaan hasrat dalam belajar sehingga dorongan untuk meraih cita- cita pun juga berbeda. Berdasar permasalahan tersebut, maka penulis tertarik melakukan penelitian dengan judul "Pengaruh Fasilitas Belajar dan Motivasi Belajar terhadap Hasil Belajar Siswa pada Mata Pembelajaran Ekonomi."

Mamuaya (2013) menyatakan bahwa fasilitas belajar merupakan uang atau benda-benda yang bisa memperlancar dan memudahkan suatu pelaksanaan usaha. Fasilitas belajar dapat mempermudah pelaksanaan belajar mengajar dengan tujuan pembelajaran yang diinginkan. Menurut Romadhina (2016) mengungkapkan bahwa fasilitas belajar adalah suatu hal yang 
berguna untuk mempermudah proses pembelajaran. Menurut Hariyanti (2016) indikator fasilitas belajar yang ada dirumah meliputi: ruang belajar, perangkat belajar seperti meja, kursi, dan rak buku, perlengkapan belajar seperti buku, pensil, bolpoin, dan penghapus, media pembelajaran seperti komputer/ laptop, handphone, wifi, koran, majalah, dan buku penunjang belajar. Sarana penunjang seperti motor, mobil, dan angkutan umum.

Slameto (Slameto, 2010) menjelaskan motivasi peserta didik dalam belajar bisa dilihat dari: antusiasme peserta didik yang tinggi, tertarik pada mata pelajaran yang diajarkan serta gurunya, selalu mengingat dan mempelajari kembali pelajarannya, slalu mengendalikan perhatian kepada guru serta bisa terkontrol oleh lingkungannya.

Menurut Uno (Uno, 2014) menjelaskan bahwa motivasi belajar dipengaruhi oleh sesuatu yang menjadi kekuatan dalam diri seseorang sehingga seseorang tersebut bisa melakukan atau bertindak sesuatu, biasa disebut motif. Motif bisa dilihat dengan melihat tingkah lakunya, dorongan, rangsangan serta pembangkit tenaganya yang muncul untuk bertingkah laku.

Lebih lanjut Sardiman (2011) menjelaskan motivasi merupakan dorongan yang muncul dalam diri seseorang untuk mencapai tujuan dengan melakukan suatu tindakan. Berdasarkan pendapat para ahli disimpulkan bahwa motivasi belajar merupakan suatu dorongan dalam diri peserta didik untuk mencapai suatu tujuan yang ingin diperoleh. Siswa akan dapat menyimpan materi dalam jangka waktu yang panjang, menguasai serta memahami apa yang telah dipelajari. Siswa dengan motivasi tinggi, usaha yang dilakukan untuk mencapai tujuan juga besar, pada akhirnya hasil belajar yang diterima juga baik.

Menurut Uno (2014) indikator suatu motivasi dalam belajar yaitu adanya rasa butuh dan keinginan dalam belajar, memiliki hasrat untuk berhasil, adanya penghargaan dalam belajar, memiliki cita-cita dan harapan untuk masa depan, lingkungan belajar yang kondusif, serta adanya rasa menarik dalam belajar.

Menurut Rohmah (2015) hasil belajar dipengaruhi oleh faktor lingkungan yang alami, maksudnya tempat tinggal asli dari peserta didik yang tidak ada pencemaran lingkungan. Lingkungan sosial budaya maksudnya terdapat hubungan sebagai makhluk sosial yang saling berinteraksi satu sama lain, faktor instrumental yaitu perangkat atau alat berupa guru, sarana prasarana, serta kurikulum yang digunakan untuk mencapai suatu tujuan. Kondisi Fisiologi adapun faktor dari kondisi fisiologi yakni kesehatan jasmani yang dimiliki seseorang, memiliki gizi yang cukup karena jika memiliki gizi yang kurang akan mudah merasa lelah, mengantuk sehingga akan kesulitan dalam menerima pembelajaran, kondisi panca indera yang baik seperti postur tubuh, hidung, pengecap, mata, serta telinga. Kondisi psikologis disini dijelaskan juga tentang faktor psikologis yang bisa mempengaruhi hasil belajar dan proses belajar siswa, minat merupakan suatu rasa tanpa paksaan untuk tertarik atau tidak suka trhadap suatu hal. Minat juga merupakan hubungan antara lingkungan luar dengan diri sendiri, semakin kuat hubungannya maka minat yang muncul juga semakin besar. Kecerdasan disini dijelaskan bahwa kecerdasan dan umur seseorang memiliki hubungan. Ketika umur seseorang semakin bertambah maka semakin tinggi cara berpikirnya. Bakat banyak yang mengatakan bahwa bakat kemampuan seseorang atau potensi yang dimiliki sejak lahir yang perlu dilatih dan dikembangkan secara terus-menerus. Bakat dan pembawaan adalah suatu hal yang berbeda, perbedaannya terletak pada pengertiannya. Bakat biasanya lebih condong ke potensi-potensi yang dimiliki seseorang, sedangkan pembawaan dapat diartikan lebih luas yakni sifat, karakteristik/ciri-ciri, gen yang telah dibawa sejak lahir. Jika bakat seseorang memiliki bakat dan disembunyikan maka bakat tersebut akan terpendam dan tidak pernah berkembang, adapun macam- macam bakat yang dimiliki seseorang yakni menari, olahraga, akademik, menyanyi, bermain music, designer, dll. Motivasi adanya suatu dorongan yang diberikan untuk membuat seseorang melakukan sesuatu hal, sehingga adanya motivasi yang tepat dapat membantu seseorang dalam mengembangkan bakta yang dimiliki. Peserta didik mudah menguasai dan memahami ilmu pengetahuan apabila memiliki kemampuan kognitif. Tiga kemampuan kognitif yang harus dikuasai oleh peserta didik, yakni persepsi penerimaan informasi atau pesan yang diterima oleh otak. Mengingat suatu hal yang muncul kembali dalam pikiran individu. Berpikir mempertimbangkan atau memutuskan suatu hal dengan menggunakan akal budi.

Terjadinya suatu perubahan kearah yang lebih baik oleh peserta didik berarti hasil belajarnya telah ideal. Hasil belajar adalah kemmapuan yang didapatkan seseorang setelah melalui kegiatan belajar (Abdurrahman \& Somantri, 2011). Indikator dalam penelitian siswa adalah nilai ulangan harian (UH).

Nilai yang dipeoleh siswa dalam mata pelajaran ekonomi bermacam-macam. Faktor motivasi belajar dan fasilitas belajar dapat mempengaruhi tinggi rendahnya nilai belajar peserta didik.Penelitian ini bertujuan untuk mendeskripsikan pengaruh motivasi belajar terhadap hasil belajar peserta didik pada mata pelajaran ekonomi, 
mendeskripsikan pengaruh fasilitas belajar terhadap hasil belajar peserta didik pada mata pelajaran ekonomi, serta untuk mendeskripsikan motivasi belajar terhadap hasil belajar peserta didik pada mata pelajaran ekonomi.

\section{METODE}

Penelitian ini menggunakan metode kuantitatif. Hal ini berarti data yang diperoleh berupa pengumpulan data atau angka yang memberikan gambaran terhadap objek yang telah diteliti melalui data yang didapat dari populasi dan sampel.

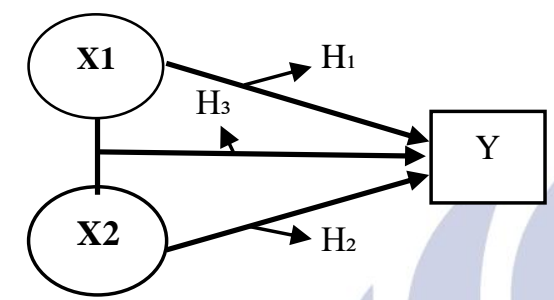

Gambar I: Rancangan Penelitian Sumber: Diolah Peneliti 2019

Peserta didik sebanyak 79 siswa kelas XI IPS yang terdiri dari kelas XI IPS 1, XI IPS 2, dan XI IPS 3 SMA Muhammadiyah 4 sebagai populasi dalam penelitian ini. Populasi tersebut mencakup Peserta didik laki-laki dan perempuan.

Ssampel dalam penelitian ini diambil dari seluruh jumlah populasi. Dengan hal tersebut maka akan membuat generalisasi dengan kesalahan yang kecil.

Teknik Pengumpulan Data

Perolehan data mengenai permaslahan terkait fasilitas belajar, hasil belajar, dan motivasi belajar peserta didik kelas XI IPS SMA 4 Muhammadiyah 4 Surabaya dilakukan dengan menggunakan teknik wawacara yang terstruktur.

Penelitian ini menggunakan angket berupa pertanyaan langsung atau tertutup satau pernyataan untuk mendapatkan data yang bekaitan dengan hasil belajar, motivasi serta fasilitas belajar.

Data foto kegiatan penelitian dan profil peserta didik didapatkan menggunakan metode dokumentasi.

\section{Teknik Analisis Data}

Uji Hipotesis Koefesian Determinasi $\left(\mathrm{R}^{2}\right)$, uji Asumsi Klasik serta Analisis Regresi Linier Berganda digunakan dalam penganalisisan data pada penelitian ini.

\section{HASIL DAN PEMBAHASAN}

Hasil

Nilai t hitung berdasar pada hasil uji t sebesar 2.110 dengan nilai signifikansinya 0.013 . Karena t hitung $2.110>\mathrm{t}$ tabel 1.991, maka hipotesis pertama diterima dengan bunyi diduga fasilitas belajar berpengaruh secara signitifikan terhadap hasil belajar siswa SMA Muhammadiyah 4 Surabaya pada mata pelajaran ekonomi. Hal tersebut berarti variabel fasilitas belajar secara signifikan berpengaruh positif terhadap hasil belajar peserta didik SMA Muhammadiyah 4 Surabaya.

Nilai t hitung berdasar hasil uji t sebesar 3.321, dan 0.001 nilai signifikansinya. Karena t hitung $3.321>$ 1.991, maka hipotesis pertama diterima dengan bunyi diduga motivasi belajar berpengaruh secara signitifikan terhadap hasil belajar siswa SMA Muhammadiyah 4 pada mata pelajaran ekonomi. Artinya, variabel motivasi belajar peserta didik secara signifikan berpengaruh positif pada hasil belajar peserta didik SMA Muhammadiyah 4 Surabaya.

Nilai F hitung berdasar hasil output sebesar 5.520, dan 2.331 untuk $F$ tabel. Hasil tersebut berarti $F$ hitung $>$ F tabel. Untuk membandingkan nilai $\mathrm{F}$ tabel dan $\mathrm{F}$ hitung bisa dilihat dari nilai signifikansinya yang dalam penelitian ini sebesar 0.006 dengan alfa $(\alpha)$ sebesar 0.050 . Hasil ini menujukkan $0.006<0.050$.

Dilihat dari analisis tersebut berarti H0 ditolak, berarti bisa ditarik kesimpulan bahwa motivasi belajar dan fasilitas belajar berpengaruh pada hasil belajar peserta didik. Dengan demikian pada hipotesis ke- $3, \mathrm{H} 0$ ditolak dan Ha terbukti kebenarannya. Hipotesis ke- 3 berbunyi: diduga secara simultan motivasi belajar dan fasilitas belajar berpengaruh secara signifikan terhadap hasil belajarnya peserta didik SMA Muhammadiyah 4 Surabaya.

\section{Pembahasan}

\section{Pengaruh Fasilitas Belajar terhadap Hasil Belajar} siswa.

Variabel fasilitas belajar mampu mempengaruhi secara signifikan dan positif pada hasil belajar peserta didik SMA Muhammadiyah 4 Surabaya jika dilihat berdasar analisis deskripti uji t nya. Artinya hasil belajar peserta didik bisa dipengaruhi secara signifikan dan positif oleh fasilitas belajar . Pada hipotesis yang pertama yaitu ada pengaruh fasilitas belajar secara signitifikan terhadap hasil belajar dapat diterima, sehingga bisa disimpulkan untuk belajarnya peserta didik membutuhkan pemenuhan fasilitas belajar.

Fasilitas belajar yang lengkap mampu memudahkan peserta didik dalam memahami materi, sehingga peserta didikk tidak hanya membutuhkan ketika berada disekolah saja tetapi dirumah peserta didik juga membutuhkan fasilitas belajar. Hal ini sejalan dengan penelitian yang pernah dilakukan oleh Romadhina (2016), Kurniawan (2014), Siahaan dan Pramusinto (2018) yang menyatakan bahwa fasilitas belajar sangat 
berguna untuk memudahkan proses pembelajaran. Dalam hal ini keterkaitan antara pemenuhan fasilitas belajar dengan pemaksimalan penggunaan fasilitas belajar harus seimbang agar perolehan hasil belajar juga maksimal.

Mayoritas siswa SMA Muhammadiyah 4 Surabaya memiliki fasilitas belajar yang tidak terlalu banyak dan tidak juga terlalu sedikit yang seharusnya terpenuhi atau bisa dimasukkan dalam kategori sedang. Jika dilihat dari hasil belajar yang diperoleh mayoritas hasil belajarnya tidak terpenuhi. Peserta diidk akan mudah melakukan proses pembelajaran di rumah apabila fasilitas yang diberikan lengkap. Hal tersebut akan bertolak belakang dengan peserta didik yang fasilitas di rumahnya tidak terpenuhi secara optimal, sehingga peserta didik tersebut akan kesulitan dalam proses pembelajaran di rumahnya.

Pengaruh Motivasi Belajar terhadap hasil Belajar Siswa.

Variabel motivasi belajar peserta didik mampu mempengaruhi hasil belajar peserta diidk secara signifikan dan positif jika dilihat dari hasil analisis uji t. Hal ini menunjukkan bahwa hasil belajar peserta didik di sekolah dikontribusi oleh motivasi belajarnya, sehingga hipotesis kedua diterima yaitu motivasi belajar peserta didik secara signifikan dipengaruhi oleh motivasi belajar. Hal tersebut berarti hasil belajar akan baik jika diimbangi dengan memaksimalkan dukungan berupa pemberian motivasi.

Motivasi dapat diperoleh dari orang tua di rumah, guru disekolah bahkan teman di lingkungan sebaya. Motivasi diberikan bertujuan supaya hasil belajar peserta didik di sekolah meningkat. Senada dengan itu Sobandi (2017), Warti (2016), dan Stevani (2016) pernah menyatakan bahwa motivasi belajar berpengaruh dalam meningkatkan hasil belajar peserta didik. Peserta didik yang memiliki motivasi tinggi cenderung merasa tertantang untuk memahami materi yang guru sampaikan.

Motivasi selalu dikaitkan dengan pembelajaran di sekolah utamanya hasil belajar peserta didik. Peserta didik yang memiliki motivasi belajar tinggi dapat dilihat dari materi yang telah dikuasai, dari kecakapan dan keterampilan yang dimiliki, dari cara menganalisa bahkan memecahkan sebuah permasalahan dan bagaimana cara siswa tersebut dalam bertindak guna merencanakan langkah pembelajaran yang akan dilakukan. Sesuai penelitian terdahulu oleh Astuti dan Sukardi (2012) yang menyatakan bahwa keberhasilan dalam penguasaan konsep dari kegiatan belajar di dalam kelas berarti akan optimal pula hasil belajarnya.

Mayoritas siswa SMA Muhammadiyah 4 Surabaya memiliki motivasi belajar sedang. Rata- rata dari mereka kurang mendapatkan motivasi ataupun memotivasi dirinya sendiri, sehingga tidak ada keinginan untuk belajar. Hal tersebut berdampak pada ketidakmaksimalnya hasil belajar. Senada dengan hal ini, Riyani dan Palupiningdyah (2015) menyatakan bahwa peserta didik yang rendah dalam prestasi belajar belum tentu disebabkan oleh rendahnya kemampuannya bias jadi diakibatkan lemahnya motivasi serta kurangnya dorongan peserta didik untuk belajar.

\section{Pengaruh Fasilitas Belajar dan Motivasi Belajar terhadap hasil Belajar Siswa.}

Motivasi belajar dan fasilitas belajar berdasar hasil analisis uji $\mathrm{F}$ berdampak positif serta signifikan terhadap peningkatan hasil belajar peserta didik mata pelajaran ekonomi. Hal ini berarti peningkatan hasil belajar peserta didik di sekolah dikontribusi oleh motivasi belajar serta fasilitas belajar. Sesuai dengan hippotesis ketiga yang menyatakan bahwa fasilitas belajar dan motivasi belajar berpengaruh secara signifikan terhadap hasil belajar dapat diterima. Hal ini menunjukkan bahwa hasil belajar akan baik jika diimbangi dengan memaksimalkan pemeberian fasilitas belajar dan memberikan dukungan berupa pemberian motivasi.

Hasil belajar adalah output atas proses belajar yang mana harus terpenuhi bagaimanapun caranya. Dalam hal ini bisa memenuhi kebutuhan belajarnya atau memberikan motivasi. Peningkatan hasil belajar peserta didik di sekolah diakibatkan dari motivasi belajar serta pemberian fasilitas belajar yang. Hasil penelitian tersebut didukung oleh pendapat Riyani dan Palupiningdyah (2015) menyatakan bahwa hasil belajar peserta didik bias meningkat apabila motivasinya cukup serta fasilitas belajar yang memadai.

\section{PENUTUP}

Berdasarkan hasil penelitian dapat ditarik kesimpulan bahwa motivasi belajar peserta didik bisa berpengaruh positif serta signifikan terhadap peningkatan hasil belajar peserta didik kelas XI SMA Muhammadiyah 4 Surabaya. Fasilitas belajar peserta didik berpengaruh secara positif dan signifikan terhadap hasil belajar ekonomi siswa kelas XI IPS SMA Muhammadiyah 4 Surabaya. Fasilitas belajar dan motivasi belajar secara bersama- sama berpengaruh signifikan dan positif terhadap hasil belajar ekonomi siswa kelas XI IPS SMA Muhammadiyah 4 Surabaya.

Saran yang diberikan oleh peneliti berdasar pada hasil penelitian yakni pemaksimalan fasilitas belajar baik disekolah maupun dirumah sangat dibutuhkan oleh siswa untuk peningkatan hasil belajar. Sebaiknya orang tua dan guru sering memotivasi siswa terutama berkaitan dengan masa depan agar siswa memiliki keinginan belajar yang tinggi. 
Untuk peneliti berikutnya yang akan melaksanakan penelitian yang sama disarankan untuk menambah dan memperbarui teori- teori mengenai fasilitas belajar, motivasi belajar dan hasil

\section{DAFTAR PUSTAKA}

Abdurrahman, M., \& Somantri. (2011). Dasar-dasar Metode Statistika untuk Penelitian. Bandung: Pustaka Setia.

Aunurrahman. (2014). Belajar dan Pembelajaran. Bandung: Alfabeta.

Riyani, E. \& P. (2015). Pengaruh Motivasi dan Fasilitas Belajar Terhadap Hasil Belajar Siswa Mata Pelajaran IPS Ekonomi Kelas VIII SMP Negeri 1 Karangreja Purbalingga. Economic Education Analysis Journal, 4.

Rohmah, N. (2015). Psikologi Pendidikan. Yogyakarta: Kalimedia.

Sardiman. (2014). Interaksi dan Motivasi Belajar Mengajar. Jakarta: Raja Grapindo Persada.

Sardiman, A. . (2011). Interaksi \& Motivasi Belajar Mengajar. Jakarta: PT. Raja Grafindo.

Slameto. (2010). Belajar dan Pembelajaran. Jakarta: Rineka Cipta.

Sudjana, N. (2013). Penilaian Proses Hasil Belajar Mengajar. Jakarta: PT Remaja Rosdakarya.

Sukmadinata, N. S. (2011). Landasan Psikologi Proses Pendidikan. Bandung: PT Remaja Rosdakarya.

Uno, H. B. (2014). Teori Motivasi \& Pengukurannya. Jakarta: Bumi aksara.

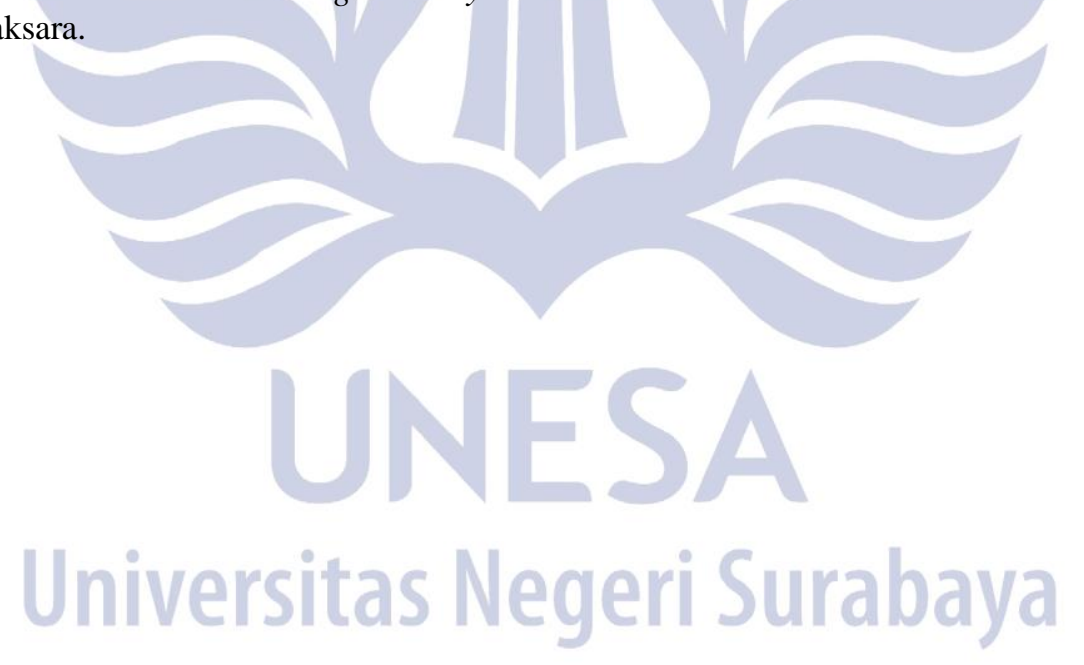

